\title{
Analysis of the Description of Experiential Marketing, Store Atmosphere and Local Retail Customer Satisfaction of Gorontalo City, Indonesia
}

\author{
Umin Kango ${ }^{1}$, Widji Astuti², Achmad Firdiansjah ${ }^{3}$ \\ ${ }^{1-3}$ University of Merdeka Malang, Indonesia
}

\begin{abstract}
The trend of economic growth in Gorontalo City, surpassing national economic growth, is one reason why retail businesses develop here. This study aims to describe experiential marketing, the atmosphere of a local modern retail satisfaction store in Gorontalo City. The research was conducted on the local retail type of Gorontalo City, Indonesia. The population of this study was local minimarket retail customers in Gorontalo City. The sample size used was 190 respondents. The average value of the Experiential Marketing indicator is 4.05, which means that respondents tend to agree that retailers have good relationships with consumers directly. The sales assistant communicates well with consumers to maintain relationships, thus establishing good relationships with consumers directly.Moreover, the sales assistant to communicate well with consumers to maintain relationships has contributed to the Relate indicator. The description of the shop atmosphere's average value is reflected through four indicators, namely the Store Exterior, General Interior, Store Layout, Interior Display, and Store Layout indicators, which have the highest rating compared to other indicators with an average value of 4.34. Customer Satisfaction's average value is 3.99, meaning that the respondent feels satisfied shopping at local modern retail. This is reflected in the respondent's statement who has the highest average value, namely, Saying positive things about retail to others. In the following statements, the respondent tends to agree to service exceeded expectations. Customer Satisfaction is formed by indicators of saying positive things about retail to others, in the aftermath of the service exceeding expectations, then intending to shop again.
\end{abstract}

Keywords: Customer Satisfaction, Experiential Marketing, National economic growth.

\section{INTRODUCTION}

The economic growth trend of Gorontalo City, surpassing the national economic growth, is one reason why retail businesses develop here. The Central Statistics Agency (BPS) of Gorontalo City noted that economic growth in 2018 was $7.88 \%$ compared to 2012, which was only $7.43 \%$ (Gorontalo City in Numbers, 2018).

In the context of the retail market, slow market growth, and intense competitive pressures require retail owners to retain existing or existing customers. Customers' tendency to be willing to make the first purchase and then to make the next purchase over and over again can occur if the performance of the promotion matches their wishes. In Kotler's opinion: fulfilling and satisfying the needs and desires of target consumers better than competitors will make consumers loyal [1].

Customer satisfaction is a reference for the success of the retail business. It is creating offers that genuinely reach the capabilities and needs of consumers. Customer satisfaction is manifested in the expression of a person's happy or disappointed feelings from a comparison between his impression of the performance (or results) of a product and his expectations. The satisfaction obtained by customers can bind them to buyback. At that point, the customer becomes loyal to the shop.

About customer satisfaction can be caused by several scenarios that are interrelated and affect customer loyalty. The first is the image of the shop. This is related to excellence and the creation of new things to meet consumer needs. Shop image can be shown through facilities, shop services, and convenience.

According to Oloughlin, O. Christina [1] research, store image is an impression that consumers and the public have of a shopping center as a reflection of the evaluation of the shopping center concerned. According to [2] , store image is also related to perceptions and attitudes based on stimuli received through the consumer's five senses. The stimulus is the form of stimulation received through the senses that can be seen, heard, smell, touch, and taste that can affect the response.

Second, customer satisfaction can also be created because of experiential marketing prepared by retail marketing. This relates to how customers' emotional elements are stimulated to produce various experiences for consumers when shopping. 
Stimulating the elements of sense, feel, think, act, and experiential marketing is used to attract customers so that customers can feel satisfied. The study of [3], [4] and [5] show that experiential marketing influences customer satisfaction.

According to [6], experiential marketing is the ability of a product to offer emotional experiences to touch consumers' hearts and feelings. [6] analyzes from two aspects, first, strategic experiential modules (SEMs) which are the foundation of experiential marketing and consist of experience through sensory (sense), useful experience (feel), creative cognitive experience (think), physical experience and overall lifestyle (act) and experiences arising from relationships with certain reference groups or certain cultures (relate). Second, experiential providers (ExPros), which are tactical tools to implement experiential marketing consisting of communications, visual/verbal identities, products, co-branding, environment, electronic media/websites, and people.

Experiential marketing is more than just providing information and opportunities for customers to experience the benefits of the product or service itself, according to [7] , but it also evokes emotions and feelings that have an impact on marketing, especially sales. So, in today's era, marketing wars are not in the market but customers' minds.

The study was conducted by [8], [5], [9], and [10] show that experiential marketing influences customer loyalty. Next, customer loyalty can also be caused by the shop atmosphere, which is related to the atmosphere of the arrangement of goods and other physical facilities that can affect consumers' emotions and provoke them to make repeated purchases.

The shop atmosphere is a planned atmosphere that suits the target market and attracts consumers to buy. A store's atmosphere can cause or influence purchases. The emotional state will make two feelings appear at once, namely feeling happy and arousing the desire to shop. This is very important for the retail business to master.

The store atmosphere can be one of the driving forces for consumers to be loyal even though it is only specific, meaning it applies to individual market segments. Here the locality aspect needs to be considered by retailers. Thus, store atmosphere relates to creating memorable customer impressions such as interior, layout, and design as well as point of purchase and retail store decoration designed to create an effect on customer perceptions and emotional responses. Moreover, the success of designing a store atmosphere, will have implications for customer satisfaction - although it is not an easy thing to satisfy all customers.

It is interesting to see how the three variables described above, and their relationship with customer satisfaction are applied by retailers in Gorontalo City, both by national retailers and by local retailers. Whether these variables influence each other and affect customer loyalty still requires further measurement and study.

The results may be different, even though all retail stores apply the same concept. For example, regarding shop image, different results are found in research by [11] and [12]. According to him, the store image does not affect consumer loyalty, likewise with experiential marketing. Different results were shown by [3], that experiential marketing does not significantly affect customer loyalty. As for the shop atmosphere, different results that the shop atmosphere does not have enough influence on customer loyalty. This study aims to describe experiential marketing, the atmosphere of a local modern retail satisfaction store in Gorontalo City.

\section{LITERATURE REVIEW}

According to [2] there are methods of digging, namely: Complaint and Suggestion System, Every customer-oriented organization (customer-oriented) needs to provide broad opportunities for its customers to convey their suggestions, opinions, and complaints. The media used can be in the form of suggestion boxes placed in strategic places (easy to reach or frequently passed by customers), comment cards (which can be filled in directly or sent via post to the company), memorable toll-free telephone lines, and others. However, because this method is passive, it is difficult to get a complete picture of customer satisfaction or dissatisfaction.

Ghost Shopping, One way to get a picture of customer satisfaction is to hire several people (ghost shoppers) who play or act as potential customers/buyers of the company and competitors. The ghost shoppers then report their findings regarding the strengths and weaknesses of the company's and competitors' products based on their experience when purchasing these products. Besides, ghost shoppers also need to observe how companies and competitors serve customer requests, answer customer questions, and respond to complaints.

Lost Customer Analysis, Companies should contact customers who have stopped buying or who have switched suppliers to understand why this is happening and to be able to take further improvement or improvement policies. It is not only an exit interview that needs to be done, but monitoring customer loss rates are also significant, where an increase in the customer loss rate indicates a failure to satisfy customers. 
Customer Satisfaction Surveys, Generally much research on customer satisfaction is conducted by survey research, either by postal, telephone, or personal interviews. Through a survey, the company will get responses and give a positive sign that the company is paying attention to customers.

Regarding the measurement of customer satisfaction, [13] uses three items in the measurement of satisfaction, namely, 1) Overal Satisfaction (overall satisfaction) is the result of evaluation and experience of current consumption originating from habits, constraints, and service standardization; 2) Confirmation of expectation (confirmation of expectations) is the level of conformity between performance and customer expectations and 3) Comparison of Ideal is product performance compared to ideal conditions according to customer perceptions.

Experiential marketing can be said to provide information that is more than just information about a product or service. According to [6], experiential marketing is an approach to acquire and retain consumers by presenting unique, positive, and impressive experiences. Thus, Experiential marketing is a marketing concept that emphasizes the performance of products and services that provide emotional experiences that touch customers' hearts and feelings.

Based on the above opinion, experiential marketing can be interpreted as a marketing concept that emphasizes performance, products, and services that provide emotional, unique, positive, and impressive experiences to consumers, as well as touching hearts and feelings, so they want to use the company's products and services. The conceptual framework in managing the accumulated experience of customers (experiential marketing) for a company can be divided into two concepts, namely Strategic Experiential Modules (SEMs) which are the primary form of Experiential Marketing and Experience Providers (ExPros) as a tool. Tactical to implement Experiential Marketing.

Still, according to [13] Experiential Modules describes five customer experiences, which are the basis of Experiential Marketing. The five things are sense, feel, think, act, and relate, each of which can be explained as follows: The sense is an experience that relies on feelings to create experiences through the customer's five senses. Marketing sense can differentiate companies and products, motivate customers, and add value to products. Marketing sense must be able to influence the five senses of the customer. The senses the company offers must be well stimulated to provide a memorable experience.

[13] emphasizes that the purpose of sense is to give the impression of beauty, pleasure, beauty, and satisfaction through sensory stimuli of the customer's five senses. A company can use three strategic sense marketing objectives to differentiate its products or services, motivate consumers to buy these products, and provide value to customers. First, the sense is the differentiator if a company offers a specially designed product/service. Second, sense as a motivator if a company can motivate customers to buy the company's products without excessive advertising. Third, sense as a value provider if a company can provide unique value to customers.

The three senses are carried out through the S-P-C (Stimuli, Process, Consequences) model, namely to differentiate products through sensory attraction with appropriate stimuli. To motivate customers, we need an identification process, then to get value from customers, we need to know the consequences of these five senses.

Feel seeks to attract the customer's deepest feelings and emotions to create a feeling of the customer experience ranging from casual feelings to the intense emotional level of pride and prestige. The strongest feeling occurs when consuming the product. Therefore, the usual promotion will not touch the emotions of customers in consuming these products. To achieve the needed feel is an approach that can arouse customer emotions by making customers feel good. Consumers will love the product and the company, and when customers feel bad, consumers will avoid the product and leave the company. So if a marketing strategy can consistently make customers feel better, consumers will build strong customer loyalty.

Feel in experiential marketing is closely related to affective experience. In measuring this feel, a marketer must consider the mood and emotions of the customer. Experiential marketing is said to be successful if it can create customers' moods and emotions according to their wishes. The mood can be obtained through unique stimuli where the customer is not aware of it, while emotions are deliberately cultivated/done by the company, for example, emotions of jealousy, anger, or even love.

Think, The purpose of thinking is to bring customers to think more deeply and creatively to provide good opinions on the company's products and services. [13] expresses the principles of think as follows: Surprise, this surprise is essential to attract attention and invite customers to want to think creatively. A condition resulting from the customer getting more than initially expected, or something completely different from what the customer previously thought, results in pleasure feelings.

Intrigue, If the surprise departs from the expectation in mind, intrigue is outside that frame of mind because the promotion arouses customer curiosity. 
Provocation. Provocation can cause extraordinary attention from the target market (read: customers, prospective customers) because it stimulates discussion and controversy, but this becomes too risky if it goes through the boundaries of moral ethics and law in specific communities.

Act marketing aims to create experiences that are related to body experiences. Long-term patterns of behavior and lifestyle and experience as a result of interactions with other people, thereby enriching the customer's life with physical experiences. Act exposes customers to other alternatives.

Consumers will make purchases because of external influences (referent beliefs) in the form of social norms and opinions and the influence from within (outcome beliefs) in the form of attitudes and pressures. Experiential marketing aims to create a medium that supports customers to interact, combining external influences with customer feel and think to become an action that will produce memorable experiences (memorable experience).

Relate marketing often occurs as a result of sense, feel, think, and acting experience. Relate is developed outside personal relationships and personal feelings but adds to the individual experience in relationships with other people, society and culture reflected in the brand. As the last type, relate affects relationships with other people. Social groups (within the scope of work, ethnicity or lifestyle) or in a more external environment such as nation and state, so that it becomes useful support to add to the customer experience of socio-cultural interactions with customer needs for social identity The key to relating is choosing the right reference and group appeal that can create a differentiated social identity for customers by engaging in the community.

The shop atmosphere is the creation of a shop atmosphere through visuals, settings, light, music, and aroma that can create a comfortable buying environment to influence consumers' perceptions and emotions to make purchases. The overall design that was created aims to build a store image and build store characteristics that affect potential customers' emotional state to make purchasing decisions. According to [14], "The store atmosphere is a planned atmosphere by the target market and which can attract consumers to buy." This opinion emphasizes that what causes or affects a purchase is an emotional state.

The store atmosphere is one element of the retail marketing mix involved in creating a shopping atmosphere. The atmosphere is the key to attracting and impressing consumers with the in-store shopping experience. The store atmosphere is an essential characteristic for every business to create a comfortable atmosphere for consumers so that it makes consumers want to stay in the store for a long time and indirectly stimulates consumers to make purchases. Retailers must manage the atmosphere (atmosphere) in the outlet so that the objectives of increasing customer visits, increasing sales, and stimulating a favorable customer image can be achieved.

There are at least two kinds of shopping motivations that retailers should pay attention to in providing a suitable store atmosphere. First, it is a group-oriented to utilitarian motives that are more concerned with functional aspects. Even so, this group will at least choose outlets that are well organized, clean, and air-cooled. Visual attractiveness and additional perks are not too important for consumers. The second is a recreation-oriented group. The ambiance factor, visual merchandising, and complete facilities determine consumer decisions in visiting an outlet. Therefore, retailers must dress up their shopping places as attractive as possible. A store's atmosphere has elements that all influence the atmosphere the store is trying to create. The shop atmosphere elements consist of a stone exterior, general interior, store layout, and interior display.

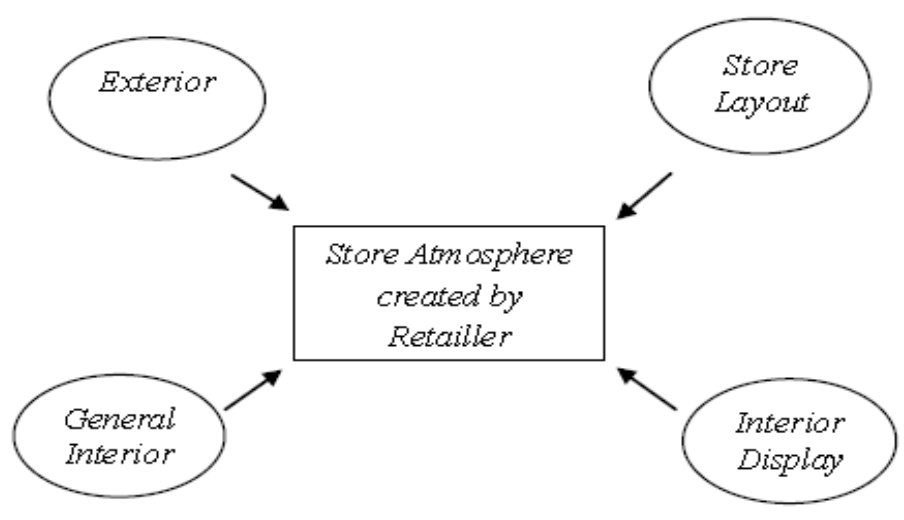

Figur 1

Store Atmosphere Element

Store exterior or the front of a shop reflects the stability and robustness of the company's spirit and the nature of the activities that exist in it and can create trust and goodwill for consumers. Store exterior serves as an identification or recognition mark, so it often represents a symbol. Parts of the store exterior are the outer building, shop signboard, entrance, building area, shop design, parking facilities, shop yard, and vehicle security. 
The general interior of a store must be designed to maximize visual merchandising. As is known, advertisements can attract buyers to come to the store, but the main thing that can make sales after the purchase is in the store is the display. A good display can attract consumers' attention and help observe, check, and select items quickly, and make purchases when consumers enter the store. This interior's general impression can be created through the attractive color of the shop walls, room lighting, the music being played, neat arrangement of goods shelves, friendly employees, shop cleanliness, and the smell of smells and the air in the shop.

\section{RESEARCH METHODS}

\subsection{Research design}

The approach used in this research is quantitative research modeling with an explanatory research design: research that intends to describe the pattern of relationship or influence between two or more variables. This relationship pattern can be symmetrical, causal, and reciprocal [15]. The pattern of influence that will be examined in this study is the effect of store image, experiential marketing, store atmosphere on customer satisfaction and loyalty. Judging from the method and level of explanation, this research is survey research, a quantitative study using the same structured and systematic questions for the respondent, and then all the answers obtained are recorded, processed, and analyzed.

\subsection{Research sites}

The research was conducted on the type of local retail in Gorontalo City, Indonesia. The research is being carried out on this retail because national retailers dominate the market, so some local modern retail companies are closed, and some are threatened with closing. Even though the trading tradition of retailers in Gorontalo City applies the concept and pattern of modern retail stores, they still lose old customers who move to national retail stores that have started operating since 2016.

\subsection{Population and Sample Research}

The population of this study was local minimarket retail customers in Gorontalo City. The population in this study is infinite. That is, the population size is so large that the population cannot be known with certainty. In these conditions, the study sample size is determined by multiplying the number of indicators from each variable by 5-10 [16]. Based on these provisions, the sample size used is 19 X $10=190$ respondents.

After determining the number of samples of 190 respondents, the sampling was carried out using purposive sampling technique, namely a sampling technique by selecting samples from among the population according to the researcher's criteria. The research sample criteria are customers who have their initiative and authority in shopping at local retailers in Gorontalo at least two times a month.

\section{RESULT AND DISCUSSION}

Experiential Marketing, all statement items on the Experiential Marketing variable have a correlation coefficient ( $\mathrm{r}$ count) more significant than the $\mathrm{r}$ table (0.142). This means that all statement items on the Experiential Marketing variable are declared valid according to the table above. Shop atmosphere, All statement items on the Store Atmosphere variable have a correlation coefficient ( $r$ count) more significant than the $r$ table (0.142). This means that all statement items in the Store Atmosphere variable are declared valid according to the table above.

Customer Satisfaction, All statement items on the Customer Satisfaction variable have a correlation coefficient ( $\mathrm{r}$ count) more significant than the $\mathrm{r}$ table (0.142). This means that all statement items on the Customer Satisfaction variable are declared valid according to the table above.

\subsection{Descriptive Analysis Results}

The descriptive analysis describes the respondent's answer about the variables studied by analyzing the frequency distribution of the respondent's answer to each indicator/item. The tendency of all respondents' answers to the questionnaire statement items to answer strongly agree, agree, neutral, disagree, or strongly disagree. Furthermore, from the respondents' frequency distribution, the mean (average) for each item is calculated. Based on the field data obtained, the distribution of respondents' answers about the statement items is described in detail below.

Experiential Marketing in this research includes sense experience, which is reflected in the statement that the local modern retail interior design is unique and the color combination of modern local retail spaces is attractive. The Feel Experience is reflected through the statement that it feels relaxed spending time while in local modern retail and feels comfortable when in local 
modern retail, while Think Experience is reflected through the statement that the products sold are varied so that it arouses a desire always to buy and the promos offered are very attractive.

The attack is then reflected in the statement that providing various alternative products following the wishes and providing services according to consumer needs. Medium Relate, which is reflected in the statement that retailers establish good relationships with consumers directly, and the sales assistant communicates well with consumers to maintain relationships. Data regarding the description of respondents' answers about Experiential Marketing which reflects that Sense Experience, Feel Experience, Think Experience, Act and Relate in modern local retail can provide an exciting shopping experience, both through product variations, alternative products, promos, and good relationships with consumers directly can be seen:

The Relate indicator's average value is $(3.96+4.15) / 2=4.05$, which means that respondents tend to agree that retailers have good relationships with consumers directly. The sales assistant communicates well with consumers to maintain relationships, thus establishing good relationships with consumers directly. The sales assistant communicates well with consumers to maintain relationships that contribute to the Relate indicator. The main thing that has the most considerable contribution or has the largest average item on the Relate indicator is the sales assistant's statement communicating good relations with consumers.

The average value of Experiential Marketing from the five indicators as a whole can be seen in Table 1 below. Descriptions of respondents' answers about Experiential Marketing from the five indicators as a whole can be seen:

Table 1

Description of Average Value in Experiential Marketing

\begin{tabular}{lll}
\hline Experiential Marketing Indicator & Average value & Rating \\
\hline Sense Experience & 4,33 & 1 \\
Feel Experience & 4,18 & 3 \\
Think Experience & 4,25 & 2 \\
Act & 4,12 & 4 \\
Relate & 4,05 & 5 \\
Experiential Marketing & 4,18 & \\
\hline
\end{tabular}

The average value of the Store Atmosphere indicator is $(3.74+3.74) / 2=3.74$, which means that respondents tend to agree that the retailer I visit has clear cashier instructions and the installation of product hints makes it easier to find. The location of the product, thus that the retailer that I visited has a cashier's sign that is visible and the installation of product indication makes it easier to find the location of the product, the main thing that has the most considerable contribution or that has the largest item on the Interior Display indicator is the retail that I Visit has cashier instructions visible and installation of product signage makes it easier to find product locations.

Description of the store atmosphere's average value, which is reflected through four indicators, namely the Store Exterior, General Interior, Store Layout, Interior Display, and Store Layout indicators, have the highest rating than other indicators with an average value of 4.34. The average value is average per indicator can be seen in table 3 .

Table 2

Description of Average Value of Store Atmosphere

\begin{tabular}{ccc}
\hline Customer Satisfaction Indicators & Average value & Rating \\
Store Exterior & 4,19 & 2 \\
General Interior & 4 & 3 \\
Store Layout & 4,34 & 1 \\
Interior Display & 3,74 & 4 \\
Atmosphere Toko & 4,06 & \\
\hline
\end{tabular}

The average value of the indicator Intend to shop again is $(3.91+3.74) / 2=3.82$, which means that respondents tend to agree to Have a desire to buy at local modern retail and desire to become regular customers of local modern retail, thus that having a desire to buy at local modern retail and desiring to be a regular customer of local modern retail has a contribution to the indicator Intend to repurchase, the main thing that has the most considerable contribution or has the largest average item on the Intend to repurchase indicator is Have a desire to buy at local modern retail.

The average value of customer satisfaction from the three indicators as a whole can be seen in Table 17 below. Descriptions of respondents' answers about Customer Satisfaction from the three overall indicators can be seen: 
International Journal of Advances in Scientific Research and Engineering (ijasre), Vol 6 (12), December -2020

Table 3

Description of Average Value on Customer Satisfaction Variable

\begin{tabular}{|ccc}
\hline Customer Loyalty Indicators & Average value & Rating \\
Service exceeded expectations & 4,04 & 2 \\
Saying positive things about retail to & 4,11 & 1 \\
others & & 3 \\
\hline Intend to shop again & 3,82 & \\
\hline Customer satisfaction & 3,99 & \\
\hline
\end{tabular}

Table 2 shows that the average value of Customer Satisfaction is 3.99, meaning that the respondent is satisfied shopping at local modern retail. This is reflected in the respondent's statement who has the highest average value, namely saying positive things about retail to others, followed by the statement. Respondents tend to agree for services exceeding expectations, followed by the next that intends to spend again. Thus, the three indicators that make up the primary value are positive things about retail to others.

The discussion is directed at answering the main research problem, namely the effect of experiential marketing, store atmosphere on loyalty through customer satisfaction of local modern retailers in Gorontalo city. The research results' discussion is described as follows: Experiential Marketing is formed from Sense experience, Feel experience, Think experience, attract, and relate. This research follows the concept developed by [17], that Experiential Marketing is formed from Sense experience, Feel experience, Think experience, attract, and relate.

Sense Experience is most appreciated by customers, reflected by the unique local modern retail interior design and attractive room color combinations. Respondents agree that the Gorontalo City Local Modern Retailers maintain their interior design and room color combinations. Observations in the field illustrate that customer respondent who shops young around 18 years to 25 years are more dominant, so that the Sense Experience indicator is a significant concern, also, to Feel experience, Think experience, attack, and especially the relationship that respondents perceive at the last rank of average. For Experiential Marketing, it needs to get local modern retailers' attention to be improved by establishing good relationships with consumers directly, and the sales assistant communicates well with consumers to maintain relationships. A phenomenon in the field illustrates that relatively young customers need good communication and relationships, so that modern retail salespeople need training on how to communicate and build good relationships with customers. Maintaining customer support for retail is very important by providing the customer shopping experience creatively and proactively.

The results of the descriptive analysis are in line with the opinion of [17], that experiential marketing is an approach to acquire and retain consumers by presenting unique, positive, and impressive experiences to consumers. Thus, Experiential marketing is a marketing concept that emphasizes the performance of products and services that provide emotional experiences that touch customers' hearts and feelings. With the opinion of [17], it is strengthened that Experiential marketing is related to marketing strategies that are wrapped in the form of activities to provide experiences that can leave an impression on the hearts of consumers.

Based on the above opinion, experiential marketing can be interpreted as a marketing concept that emphasizes performance, products, and services that provide emotional, unique, positive, and impressive experiences to consumers, as well as touching hearts and feelings, so they want to use local Modern Retail products and services in the city of Gorontalo.

The shop atmosphere is formed from Store Exterior, General Interior, Store Layout, and Interior Display. This research follows the concept developed by [14] that the Store Atmosphere is formed from Store Exterior, General Interior, Store Layout, and Interior Display. The store layout is appreciated the most by customers, in addition to store exterior, General Interior, Store Layout, and Interior Display, which is reflected in the fact that retailers visited by customers have a neatly arranged goods grouping system and the distance between shelves supports the smoothness of consumers in selecting goods. Observations in the field illustrate that customer respondents whose shops are much helped get the type of goods needed and require more efficient time. Local modern retailers in Gorontalo city have to arrange the layout of the goods and possible so that they are easily visible to first-time customers. Thus, visitors will be more efficient when shopping because they do not have to linger for the products they buy. This makes the retail atmosphere invisible to Crowded, which may discourage other potential visitors from entering the retail. Meanwhile, the Interior Display of respondents' perceptions is in the last rank, so it is necessary to get attention by placing the cashier's instructions visible and installing the product indication signs makes it easier to find the location of the product.

The descriptive analysis results reinforce the opinion that the elements of a shop atmosphere consist of a stone exterior, general interior, store layout, and interior display. These four elements must be of concern to local modern retailers and 
continuous improvements so that they can compete with national scale retailers. There are 5 (five) things that are important to note, (1) retail design can lure people to come shopping, (2) product displays are easily visible, (3) reflect business themes, (4) pay attention to the space for visitors, and (5) should not reduce the level of security (add CCTV facilities).

Customer Satisfaction is made up of exceeding expectations of service, telling positive retail things to others, and intending to shop again. This research is following the concept developed by [17], that Customer Satisfaction is formed on services that exceed expectations, says positive things in retail to others, and intends to shop again. Customers appreciate positive things from retail to others, which is reflected in that the retail customers visited say positive things to their relatives and others. This makes customers a positive promotional agent for local retailers. Satisfied customers will build long-term relationships with local retailers, so retaining customers by providing satisfaction is more efficient than recruiting new customers by spending much money to promote. Also, retail customers perceive that they intend to shop again at the last rank. This is reflected by customers wanting to become regular customers are not well appreciated. The retailer must establish a good relationship by conducting a member card program always to get new product information at a discount.

The descriptive analysis results strengthen [18] opinion that satisfaction is a pleasurable fulfillment, which is the fulfillment of customer expectations satisfactorily. Alternatively, in the perspective of [19], customer satisfaction is categorized as a post-purchase customer emotional reaction, which can be in the form of anger, dissatisfaction, irritation, neutrality, joy, or pleasure. These two views are slightly different from [20] views, who see customer satisfaction as the level of feelings after comparing perceived service performance with expectations.

Generally, customer expectations are estimates or customer beliefs about what they will receive when buying and consuming a product. Meanwhile, the perceived performance is "customer perception of what is received after consuming the purchased product."

\section{CONCLUSION}

Based on the results of research, data analysis, and discussion that has been carried out, several conclusions can be drawn as follows: Store image is formed by indicators of facilities, store services, shop activity, and convenience, which form the principal value of store image is an indicator of convenience. Respondents tend to agree that the local modern retail environment is kept clean and the self-serving shopping system makes it easy to choose products, then the second rank of the respondent's perception is the Store Service indicator, the third rank is Facilities and the lowest in the Store Activity indicator.

Indicators of Sense Experience form experiential Marketing, Feel Experience, Think Experience, Act, Relate. The indicator that forms the principal value of Experiential Marketing is the Sense of Experience. Respondents agree that the unique local modern retail interior design and the color combination of local modern retail spaces are attractive. The second rank is Think Experience, the third is Feel experience, the fourth is an extract, and the lowest is on the Relate indicator.

The store atmosphere is formed by the indicator Store Exterior, General Interior, Store Layout, Interior Display can form a Store Atmosphere, while the four indicators that form the principal value are the Store Layout indicator. Respondents tend to agree that the retailers visited have a neatly arranged system of grouping goods, and the distance between shelves supports the smoothness of consumers in choosing goods, then the second rank is Store Exterior, General Interior, the lowest is Interior Display.

Customer Satisfaction is formed by indicators of saying positive things about retail to others, in the aftermath of the service exceeding expectations, then intending to shop again. The indicator that forms the core value of customer satisfaction is saying positive things about retail to others. Customer loyalty is also formed by indicators of Repeating and Continuing Purchases, by Resilience, and is the reference. The indicators that form the principal value of customer loyalty are indicators of repeated purchases.

\section{REFERENCES}

[1] Oloughlin, O. Christina dan Germa Coenders. 2002. Application of the European Customer Satisfaction Index to Postal Services. Structural Equation Models versus Partial Least Squares. Department d'Economia, Universitat de Girona.

[2] Kotler, P., 2012. Marketing Management, Twelfth Edition. Pearson Prentice Hall. The USA.

[3] Chao, Ren-Fang. 2015. The Impact of Experiential Marketing on Customer Loyalty for Fitness Clubs: Using Brand Image and Satisfaction as the Mediating Variables. The Journal of International Management Studies, Volume 10, Number 2. 
[4] Dewi, R. Kusuma, Kumadji, S., Mawardi, M. Kholid. 2015. Experiential Marketing Terhadap Kepuasan Pelanggan Dan Dampaknya Pada Loyalitas Pelanggan (Survei pada Pelanggan Tempat Wisata Jawa Timur Park 1 Kota Wisata Batu). Jurnal Administrasi Bisnis (JAB). Vol. 28 No. 1.

[5] Zena, Putri Ara, dan Aswin, Dewanto, Hadisumarto, 2012. The Study of Relationship among Experiential marketing, Service Quality, Customer Satisfaction, and Customer Loyalty. ASEAN Marketing Journal. 4:39-46.

[6] Schmitt, B. H.,2004, Experiential Marketing: How to Get Customers to Sense, Feel, Think, Act, and Relate to Your Company and Brands. New York: Free Press.

[7] Andreani, Fransisca. 2007. Experiential Marketing (Sebuah Pendekatan Pemasaran). Jurnal Manajemen Pemasaran, Vo. 2 No. 1 April p 1-8.

[8] Kusumawati, A. Analisis Pengaruh Experiential Marketing Terhadap Kepuasan dan Loyalitas Pelanggan : Kasus Hypermart Malang Town Square. Jurnal Manajemen Pemasaran Modern, Vol. 3 No. 1. 2011.

[9] Yacob, S. Erida, Rosita, S., Alhadey, H., Mohammad, A., 2015. The Effect of Experiential Marketing on Customer's Brand Loyalty in Modern Retail Business: A Case Study of Jambi City in Indonesia. International Journal of Management Sciences and Business Research, Vol-5, Issue 1.

[10]Rianti, O., \& Oetomo, H. W. 2017. Pengaruh Experiential Marketing Terhadap Loyalitas Konsumen dengan Kepuasan Konsumen Sebagai Variabel Intervening. Jurnal Ilmu dan Riset Manajemen, Vol. 6, No, 8, hlm: 1-19.

[11]Bloemer, J., Ko de Ruyter dan Pascal Peeters. 1998. Investigating Drivers Of Bank Loyalty: The Complex Relationship Between Image, Service Quality And Satisfaction. International Journal of Bank Marketing, pp. 276-286.

[12] Beneke, J, E. Adams, O. Demetriou \& R. Solomons. 2011. The Influence Of The Youth On Their Parents' Purchasing Decisions of High-Technology Products. African Journal of Business Management. Vol.5 (10), pp. 38.

[13] Fornell, C Johnson, MD Anderson, EW Cha, and Bryant BE, 1996, The American Customer Satisfaction Index: Nature, Purpose, and Findings. Journal of Marketing, Vol.60.

[14] Kotler, Philip., Dan Armstrong, Gary. 2008. Principles Of Marketing, International Edition. Jilid 12. Prentice-Hall, London.

[15] Sugiyono. 2006. Metode Penelitian Administrasi. CV. Alfabeta. Bandung.

[16]Ferdinand, Augusty. 2006. Metode Penelitian Manajemen. Edisi Kedua, Universitas Diponegoro, Semarang.

[17] Madjid, Rahmat. 2013. Customer Trust as Relationship Mediation Between Customer Satisfaction and Loyalty at Bank Rakyat Indonesia (BRI) Southeast Sulawesi. The International Journal of Engineering and Science, Vol. 2 No. 5.

[18] Oliver, R. L., 2010. Satisfaction: A Behavioral Perspective on The Customer. New York: McGraw-Hill.

[19]Lovelock, C. H., Dan Wright, L. K., 2010. Principles of Service Marketing and Management. New Jersey: Prentice-Hall.

[20] Kotler, Philip dan Kevin Lane Keller. 2013. Marketing Management. Essex: Pearson Education, Inc. 